DEVELOPING ISLAMIC READING MATERIAL OF PROCEDURE TEXT

BASED ON SCIENTIFIC APPROACH FOR GRADE ELEVEN

AT SMA NURUL ISLAM INDONESIA MEDAN

AN ARTICLE

Submitted in Partial Fulfillment of the Requirements for the Degree of Sarjana Pendidikan

BY:

INDAH SARI DEVI

Registration Number: 2162121011

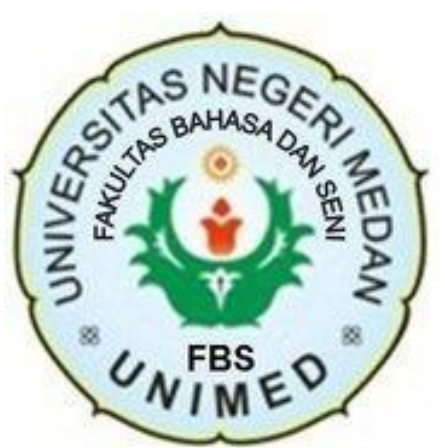

ENGLISH AND LITERATURE DEPARTMENT

FACULTY OF LANGUAGES AND ARTS

STATE UNIVERSITY OF MEDAN 


\title{
DEVELOPING ISLAMIC READING MATERIAL OF PROCEDURE TEXT BASED ON SCIENTIFIC APPROACH FOR GRADE ELEVEN AT SMA NURUL ISLAM INDONESIA MEDAN
}

\author{
*Indah Sari Devi \\ **Dr. Rahmad Husein, M.Ed
}

\begin{abstract}
Devi, Indah Sari. Registration Number: 2162121011. Developing Islamic Reading Material of Procedure Text Based on Scientific Approach for Grade Eleven at SMA Nurul Islam Indonesia Medan. A Thesis. English and Literature Department. Faculty Languages and Arts. State University of Medan, 2021.
\end{abstract}

This study aims to develop English Reading Material for Grade Eleven of Islamic Students at SMA Nurul Islam Indonesia Medan. This study was conducted by using Research and Development (R \& D) design through six stages; gathering information and data, analyzing data, designing materials, validating by experts, revising, and final product. The subject of this study were students of class XI IPA consisting of 30 students and one of the English teachers. The instrumentation for collecting the data were questionnaire and interview. After Analyzing the data, the researcher got the students' needs. The data were gathered by administrating interview to English teacher and distributing the questionnaire to 30 students to get the students' needs. The interview and questionnaire result prove that the Islamic ${ }^{1}$ students of XI IPA need English reading materials which contain Islamic content. Thus, developing English reading materials were procedure text. Then the procedure texts related to their background of knowledge. The products have been validated by two experts; English lecturer and English teacher. The average scores are 4.6 or $92 \%$ from English lecturer and 4.4 or $89 \%$ from English teacher. It means the developing materials are categorize as relevant or appropriate for grade eleven of Islamic students.

Keywords: Research and Development $(R \& D)$, reading materials, Islamic students

\footnotetext{
* Graduate Status

** Lecturer Status
} 


\section{INTRODUCTION}

\section{Background of Study}

Reading is an interaction between the reader and the writer. To understand the text well, the reader tends to comprehend the text based on their background knowledge. According to Nunan (2003:68) reading is a fluent process where in building the meaning, readers should combine information from the text with their own background of knowledge. In addition, Lems (2009:170) states that reading is an evolving interaction between the text and the background knowledge of the reader.

In teaching and learning process, teacher should consider the teaching materials which are used in the class. Textbook is one of the teaching materials which are commonly used. It is kind of printed materials which have an important part in teaching and learning process. According to Tomlinson (1999:2), textbook is a main learning material which is usually used by teacher and students. The textbook is an essential part of teaching and learning. As the implementation of Curriculum 2013, the government also developed a textbook to support the curriculum.

Islamic schools/madrasah (public and private) is under the management of the Ministry Religious affairs that is expected not only master in general education but also has strong understanding of religious and moral values based on the tenets of Islam. By inserting Islamic themes through English material, students are expected not only have good ability in reading but also have deep knowledge of Islamic tenet. Therefore the misunderstanding of Islamic tenets can also be avoided.

Furthermore, Teaching English as a Foreign Language (TEFL) is more meaningful if the teachers are able to integrate not only the culture in the society where the students live but also the local wisdom such as the values in the students' religion. Qamariah (2015) reported that the materials were developed in accordance with the principles of School-based Curriculum in Islamic school consisting of some tasks for the students to do and guidance to the teacher in using the material in the 
teaching learning process, and in line with the context of the student's life situation, especially the situation in their major institution.

In fact, based on researcher's observation at SMA Nurul Islam Indonesia Medan, it is found that the reading material used were similar to the textbook for Senior High School, it is also found that the textbook that they used is Pathway to English course book published by Erlangga which does not completely fulfill the need of Islamic students. Particularly in procedure text provided it is about How to make Porcelain, the process of recycling glass bottles and from tea plants to be a cup of tea that do not relate to Islamic scope. The students actually need the text which contains of Islamic content such as How to perform Hajj, How to Concoct Ruqyah medicine and How to bathe the corpse.

Considering the facts above, it is needed to develop reading text based on local need by changing the theme of the students reading text in order to improve students reading ability and strengthen students' Islamic tenet.

\section{REVIEW OF LITERATURE}

\section{Reading Comprehension}

Reading comprehension refers to the act of thinking and constructing meaning before, during and after reading by integrating information from the author with the reader's background knowledge (Snider, 1989). The ability to activate one's prior knowledge about the topic, self-question, identify main ideas and supporting detail, paraphrase and summarize are critical skills of effective comprehension development. Thus, the development and use of effective strategies before, during and after the reading process to foster reading comprehension skills is one of the most significant goals of educators (Mastropieri \& Scruggs, 1997).

\section{Procedure Text}

The procedure text is a text that is designed to describe how something is achieved through a sequence of actions or steps. It explains how people perform different processes in a sequence of steps. Procedure writing or text will show and explain how it works or how it is operated. The key words of this 
type of text is "what needs to be done?' or "what should I do?" or "How something is done?" or "How something works?” or “What to do next?” (Pardiyono, 2007); (Oshima, 2005).

\section{Content Area}

Content area reading refers to helping students better understand what they read in a particular content area course. It has been broadened in recent years to integrate reading, writing, talking, listening, and viewing in text-related learning (Vacca \& Vacca, 2005). The main idea is to use these language parts effectively to maintain high-level learning. A number of studies have shown that children could be taught strategies to improve learning of fictional and informational texts (Pressley, Johnson, Symons, McGoldrick, \& Kurita, 1989).

Content area reading movement is based on the assumption that all students can be taught to read better. In addition, all pre-service and in-service teachers who teach in conventional school setting should have information about content area literacy (Manzo, Manzo, \& Estes 2001). Because of using content area reading strategies, students increase their abilities to internalize content of courses, and develop conceptual understanding about subject matters (Stephens \& Brown, 2000).

\section{Scientific Approach}

Scientific approach is one of the learning approaches promoted by the 2013 Curriculum. This approach also emphasizes on process of searching knowledge and students as subject of learning through applying science principles. Since the students become the subject of learning, the learning method promoted is 'learning by doing' which is largely promoted by an American educator and philosopher John Dewey (1859-1952).

In addition, scientific approach in learning process means learning process which is organized to make learners actively construct concepts, laws, or principles through activities of observing, hypothesizing, collecting data, analyzing data, drawing conclusion, and communicating the concepts, laws, and principles found (Hosnan, 2014, p.39; Sadhono, 2013, p.440). It is expected to encourage students searching knowledge from multisource through observation and not to be given by teachers only. Scientific approach also emphasizes on communicating skill as well as scientific principles. As described by McCollum (2009). 
According to (Abidin, 2014, p.132; Hosnan, 2014, p.37; Kemendikbud, 2013; Mulyasa, 2014; Suharyadi, p.1350; Saddhono, 2013, p.441; Permendikbud No. 103 Year 2014), there are five stages in scientific approach, they are; Observing, Questioning, Experimenting, Associating and Communicating.

Research Methology

This research was conducted based on Research and Development (R \& D) method. This developmental research consists of six stages; 1). Gathering data and information, 2). Need Analysis, 3). Material design, 4). Validating by expert, 5). Revising, and 6). Final Product. This study was conducted at SMA Nurul Islam Indonesia Medan which is located in Jl. Halat No.20 B Medan. The subject of this research was the students of grade eleven and one of the English teacher at SMA Nurul Islam Indonesia Medan. The instruments of collecting data were questionnaires, interview and documents such as syllabus, lesson plan and textbook. The technique for collecting data were questionnaires of the students and interviews of the teacher.

\section{Data and Source of Data}

In this study, the data were the result of analysis of questionnaires, interview and documents such as syllabus, lesson plan and textbook. The questionnaires was administrated to the students and the interview was administrated to teacher to find the accurate data from the teacher about the student's need especially in procedure text in reading comprehension, the last is the documents as the data to develop the reading material.

\section{The Techniques and Instruments of Data Collection}

The data was collected from qualitative and quantitative; they are:

1. The qualitative data was obtained from questionnaires of the students and interviews of the teacher.

2. While quantitative data was obtained from questionnaires in form of percentage.

These two are the references of data analysis. 
The researcher was identified the main variables such as target needs and need analysis are needed of the students at SMA Nurul Islam Indonesia Medan. The data was obtained from questionnaires and interview are firstly collected and analyze. The data was needed to evaluate the reading materials and assess the students need in learning English. The qualitative data was analyzed by drawing the conclusion of the questionnaires and the interview. The quantitative data was analyzed by using percentage and procedure analysis. The data was firstly collected in the table, and then the researcher described the findings. Finally based on the analyses, the researcher plans the recommended reading materials especially in procedure text for Islamic school.

\section{FINDINGS}

\section{Gathering Information and Data}

Based on the questionnaire and interview conducted by researcher, the need analysis was conducted. There should be materials development which can fulfill students' needs to improve their motivation to learn English effectively.

\section{Analyzing Data}

In doing needs analysis, there were two things must be known; target needs and learning needs. Target needs analysis was done to know the objective or goal of the students in learning English; necessities; lacks and wants of the students. The learning needs analysis was done to know about the students' interest of inputs, learning preferences, student's role, teacher's role.

The reading materials of procedure text in that book were about "How to make Porcelain", "The process of recycling glass bottles" and "From tea plants to be a cup of tea". These texts were not suitable to the Islamic students because these texts didn't meet the needs or the purpose of the students to study in relation to the Islamic tenet. 
Table 4.1 Questionnaire Analysis

\begin{tabular}{|c|c|}
\hline Number of Items & Analysis \\
\hline Item 1 & $\begin{array}{l}\text { There were } 19 \text { or } 63 \% \text { respondents who said as an Islamic } \\
\text { Senior High School student, they needed to learn English } \\
\text { because English is an International language. }\end{array}$ \\
\hline Item 2 & $\begin{array}{l}\text { There were } 20 \text { or } 67 \% \text { respondents who said that their English } \\
\text { skills are currently at the level of beginner which can } \\
\text { understand simple sentences and expressions that often appear } \\
\text { in everyday life. }\end{array}$ \\
\hline Item 3 & $\begin{array}{l}\text { There were } 26 \text { or } 87 \% \text { respondents who said that texts they } \\
\text { often encounter in Islamic learning was Procedure (text } \\
\text { containing steps and procedures such as procedures for } \\
\text { performing Wudhu, Shalat and Hajj) }\end{array}$ \\
\hline Item 4 & $\begin{array}{l}\text { There were } 21 \text { or } 70 \% \text { respondents who said that reading was } \\
\text { the skills which they often used in learning or obtaining } \\
\text { information. }\end{array}$ \\
\hline Item 5 & $\begin{array}{l}\text { There were } 20 \text { or } 67 \% \text { respondents who said that the text } \\
\text { on How to make Porcelain and the process of recycling glass } \\
\text { bottles (procedure texts provided in their textbook) did } \\
\text { not related to Islamic content. }\end{array}$ \\
\hline Item 6 & $\begin{array}{l}\text { There were } 20 \text { or } 67 \% \text { respondents who said that they did not } \\
\text { easily understand text that is not close to } \\
\text { their background knowledge and experience. }\end{array}$ \\
\hline Item 7 & $\begin{array}{l}\text { There were } 24 \text { or } 80 \% \text { respondents who said that the text is } \\
\text { difficult to understand because it was not related to their } \\
\text { background knowledge and experience. }\end{array}$ \\
\hline Item 8 & $\begin{array}{l}\text { There were } 18 \text { or } 60 \% \text { respondents who said that their English } \\
\text { teacher never give an English text related to Islamic content. }\end{array}$ \\
\hline Item 9 & $\begin{array}{l}\text { There were } 20 \text { or } 67 \% \text { respondents who said that they mastered } \\
\text { more the texts about How to perform Wudhu, Prayers and Hajj. }\end{array}$ \\
\hline Item 10 & $\begin{array}{l}\text { There were } 14 \text { or } 47 \% \text { respondents who said that general they } \\
\text { want English learning which made them able to understand and } \\
\text { use every word, sentence and expression in English. }\end{array}$ \\
\hline Item 11 & There were 17 or $57 \%$ respondents who said that in the learning \\
\hline
\end{tabular}




\begin{tabular}{|l|l|}
\hline & $\begin{array}{l}\text { of reading, the form of the text they wanted were the reading } \\
\text { text consists of several paragraphs and is set up with a } \\
\text { vocabulary list. }\end{array}$ \\
\hline Item 12 & $\begin{array}{l}\text { There were } 13 \text { or } 43 \% \text { respondents who said that they } \\
\text { understand } 150-200 \text { words in a text as an input of reading } \\
\text { learning. }\end{array}$ \\
\hline Item 13 & $\begin{array}{l}\text { There were } 11 \text { or } 37 \% \text { respondents who said that in English } \\
\text { teaching and learning process, they prefer to do the tasks In a } \\
\text { small group of 3-4 people. }\end{array}$ \\
\hline
\end{tabular}

From the questionnaire, it was got the existing teaching materials contain some topics in which students have some difficulties because of the gap between the topics and students' prior knowledge, especially the topics in procedure text. Some topics are not appropriate for the students because the topic do not fulfill students' needs of learning English. What students need in learning English is the learning materials should enrich their English ability and increase their knowledge about Islamic tenet.

Table 4.2 Interview Analysis

\begin{tabular}{|c|c|c|}
\hline No. & Questions & Answers \\
\hline 1. & $\begin{array}{l}\text { What textbook is use by the students } \\
\text { of SMA NII in learning English }\end{array}$ & $\begin{array}{l}\text { They use English textbook published } \\
\text { by Erlangga }\end{array}$ \\
\hline 2. & $\begin{array}{l}\text { Does the school provide any English } \\
\text { textbook specified for students of } \\
\text { SMA NII? }\end{array}$ & $\begin{array}{l}\text { Yes, the school provide English } \\
\text { textbook for students but the textbook } \\
\text { used were similar to the textbook for } \\
\text { Senior High School }\end{array}$ \\
\hline 3. & $\begin{array}{l}\text { Do you think the students of SMA } \\
\text { NII are active in learning English? }\end{array}$ & Yes, they are active in learning English \\
\hline 4. & $\begin{array}{l}\text { Are examples of procedure text } \\
\text { available in the textbook related to } \\
\text { the Islamic content/tenet? }\end{array}$ & $\begin{array}{l}\text { No, the procedure texts are not related } \\
\text { to Islamic content }\end{array}$ \\
\hline 5. & $\begin{array}{l}\text { Do you think that one of the } \\
\text { student's difficulties in } \\
\text { comprehending the English text is } \\
\text { caused by the texts given are not } \\
\text { related to the student's background }\end{array}$ & $\begin{array}{l}\text { Yes, I think one of the student's } \\
\text { difficulties is because the texts provide } \\
\text { unfamiliar with the student's } \\
\text { background knowledge }\end{array}$ \\
\hline
\end{tabular}




\begin{tabular}{|l|l|l|}
\hline & of knowledge? & \\
\hline 6. & $\begin{array}{l}\text { In order to support the learning } \\
\text { process, are the procedure texts } \\
\text { related to the Islamic content needed } \\
\text { by the students of SMA NII? }\end{array}$ & Of course, it is needed. So that they are \\
also interested in learning English \\
\hline 7. & $\begin{array}{l}\text { In your opinion, are the procedure } \\
\text { texts related to the Islamic content } \\
\text { necessary to develop? }\end{array}$ & Yes, it is necessary to developed \\
\hline 8. & $\begin{array}{l}\text { What topics of procedure text are } \\
\text { needed to develop for students of } \\
\text { SMA NII? }\end{array}$ & $\begin{array}{l}\text { Whe topic such as how to perform } \\
\text { Whalat etc. }\end{array}$ \\
\hline
\end{tabular}

From the interview, it was known that the students' weakness in learning English is that dominantly they have lacks of vocabulary which make them have difficulty in understanding a text or a passage containing unfamiliar topic for them.

\section{DISCUSSION}

\section{Designing New Reading Materials}

From the data interpretation and analysis, the appropriate procedure text materials for reading skill of Islamic students in grade eleven were identified. The main point was the procedure text material given should related to their background of knowledge which is related to Islamic tenet. It was done not only to meet the students' need in their learning process and to easier the students in comprehending the materials so that the basic competence and indicator in syllabus could be achieved but also to strengthen students' Islamic tenet.

Design the English reading materials, the writer concluded that the texts relate to the Islamic students, there were three texts, they are: "Ruqyah Practical Method of Qur'anic Healing, Washing the Corpse, and A Step by Step Guide to Hajj”. These three texts were developed by selecting procedure text related to the Islamic students. In this development some original ideas of the writer were included. The writer design the layout of the text, make the vocabularies and added some pictures to make texts will be more interesting and also the writer developed some questions in the reading material of procedure text. 
Table 4.3 Developed Procedure Texts Materials

\begin{tabular}{|l|l|l|l|}
\hline No & \multicolumn{1}{|c|}{ Existing Procedure Texts } & No & \multicolumn{1}{|c|}{ Developed Procedure Texts } \\
\hline 1. & How to make Porcelain & 1. & $\begin{array}{l}\text { Ruqyah Practical Method of Qur'anic } \\
\text { Healing }\end{array}$ \\
\hline 2. & The process of recycling glass bottles & 2. & Washing the Corpse \\
\hline 3. & From tea plants to be a cup of tea & 3. & A Step-by-Step Guide to Hajj \\
\hline
\end{tabular}

\section{Validating by the Experts}

The developed material were evaluated or validated by two experts, Prof. Dr. Sumarsih, M. Pd.

As English lecturer and Sudian Efendi S.Pd., M.Pd. as English teacher. The validation of the materials done as mentioned below:

1. English Lecturer

English lecturer evaluated the developed English reading materials through four categories. They were dimension linguistic, process, product and content and layout. Each category has some criteria.

a. Linguistic

She categorized the developed English reading text as very good

b. Process

She categorized the developed English reading text as very good

c. Product and Content

She categorized the developed English reading text as good

d. Layout

She categorized the developed English reading text as good

2. English Teacher

Overall, he categorized the developed English reading text as good 


\section{Revising}

Based on validation above, the developed English reading material were validated by the experts and below are some revision given.

1. English lecturer suggestion

As suggested by English lecturer, to improve the layout of the image and to arrange the step of teaching material based on scientific approach arrangement.

2. English teacher suggestion

As suggested by English teacher, to add more common vocabulary in learning material (Appendix G).

\section{Final Product}

There were three developed reading materials that related to Islamic students. There are some criterions in developing reading materials and each criterion has score range 1 until 5. Score 1 means bad, score 2 means not enough score 3 means enough, score 4 means good and score 5 means very good.

The first validation was from English lecturer who validated the procedure text material for reading skills. There were four criterions which have to be considered whether the reading materials were valid or not, they are linguistic, process, product and content and layout as state on validation instrument.

Table 4.4 English lecturer's Validation Score

\begin{tabular}{|l|l|c|c|c|}
\hline No & \multicolumn{1}{|c|}{ Criteria } & $\begin{array}{c}\text { The number of } \\
\text { Criteria }\end{array}$ & Maximum Score & Score \\
\hline 1. & Linguistic & 7 & 35 & 33 \\
\hline 2. & Process and & 5 & 25 & 24 \\
\hline 3. & $\begin{array}{l}\text { Product } \\
\text { Content }\end{array}$ & 7 & 45 & 40 \\
\hline 4. & Layout & 28 & 35 & 32 \\
\hline Total & 740 & 129 \\
\hline \multicolumn{4}{|r|}{ Average $=\frac{129}{28}=4.6$ or percentage $=\frac{129}{140} \times 100 \%=92 \%$} \\
\hline
\end{tabular}


The average score of validation from the first validator was 4.6 or $92 \%$ and it was categorized as relevant. Thus, the final draft or the developed reading material materials were valid and appropriate to be used as learning materials for Islamic students in grade eleven of SMA Nurul Islam Indonesia Medan.

The second validation was from English teacher to ensure the Islamic tenet or Islamic content in reading materials were valid.

Table 4.5 English teacher's Validation Score

\begin{tabular}{|l|l|c|c|c|}
\hline No & \multicolumn{1}{|c|}{ Criteria } & $\begin{array}{c}\text { The number of } \\
\text { Criteria }\end{array}$ & Maximum Score & Score \\
\hline 1. & Linguistic & 7 & 35 & 28 \\
\hline 2. & Process & 5 & 25 & 21 \\
\hline 3. & $\begin{array}{l}\text { Product and } \\
\text { Content }\end{array}$ & 9 & 35 & 30 \\
\hline 4. & Layout & 7 & 140 & 124 \\
\hline Total & 28 & & 45 \\
\hline \multicolumn{2}{|r|}{ Average $=\frac{124}{28}=4.4$ or percentage $=\frac{124}{140} \times 100 \%=89 \%$} \\
\hline
\end{tabular}

The average score of validation from the second validator was 4.4 or $89 \%$ and it was categorized as relevant. It means that the materials were valid and appropriate to use for Islamic students of SMA Nurul Islam Indonesia in grade eleven.

Finally, the final product or developed English reading materials were valid to use as learning materials for Islamic students in grade eleven of SMA Nurul Islam Indonesia Medan.

\section{Conclusion}

The students of SMA Nurul Islam Indonesia need the English reading materials that are related to their background knowledge which is related to Islamic tenet. After analyzing the data, it can be concluded that:

1. Based on the analysis from the questionnaire and the interview it was conclude that the Islamic students of SMA Nurul Islam Indonesia Medan need the reading materials containing Islamic 
content particularly procedure text about "Ruqyah Practical Method of Qur'anic Healing, Washing the Corpse, and A Step by Step Guide to Hajj" in order to easier the students in comprehending the materials and also to strengthen students' Islamic tenet

2. The new reading materials were developed by using six phases of research and development ( $R$ \& D), they were: 1). Gathering data and information, 2). Need Analysis, 3). Material Design, 4). Validating by Expert, 5). Revising and 6). Final Product. The materials were developed based on the data of the students' needs analysis from the questionnaire that was administrated to the students, the analysis of interview from the English teacher and the existing material.

\section{REFERENCES}

Cantoni H and Gina. 1987. “Content-Area Language: Instruction Approaches and Strategies'. USA: Addison-Wesley.

Dirgeyasa I. W. 2016. "College Academic Writing A Genre-Based Perspective”. Jakarta: Kencana.

Gall M.D, Joyce P.G and Walter R.B. 1985. "Educational Research An Introduction: Seventh Edition". New York: Longman.

Graves Kathleen. 2000. "Designing Language Course: A Guide for Teachers”. Boston: Heinle and Heinle.

Lapp D, James F and Nancy F. 2008. "Content Area Reading and Learning: Instructional Strategies Third Edition". London and New York: Routledge Taylor and Francis Group.

Nugraha, I.S and Didi S. 2017. "Scientific Approach: An English Learning-Teaching (ELT) Approach in the 2013 Curriculum". Journal of English And Education. Vol.5. No. 2.

Vacca, R.T and Jo A.L.V. 2005. "Content Area Reading Literacy and Learning Across the Curriculum: Eighth Edition”. New York: Pearson.

Wilkinson, D and Peter, B. 2003. "Using Research Instrument, A Guide for Researchers". London and New York: Routledge Falmer. 